ЛАЗАРЕВ О. В., ст. викладач, УШАКОВ М. В., ст. викладач, ЛАЗАРСВА Н. М., інженер (Український державний університет залізничного транспорту)

\title{
Інтерактивні технології у викладанні безпеки руху
}

Дотримання безпеки руху поїдів залежить від дій спеиіалістів з технічного обслуговування $i$ ремонту пристроїв автоматики. Розглянуто досвід впровадження інтерактивних технологій та проблемного навчання у найбільш розвинутих державах світу. Визначено сучасні вимоги та складові компетентності спеціалістів $з$ автоматики. Стимулювання навчально-пізнавальної діяльності реалізується комп'ютерними програмами: навчальними, імітаційними та моделюючими, за допомогою розвиваючих ігор. Використання макетів залізничних пристроїв з імітуванням пошкоджень адаптує навчальний процес до практичного засвоєння матеріалу. Розглянуто умови реалізачії та завдання викладача при проблемно-оріснтованому навчанні. Втілення інтерактивних технологій у підготовку студентів з дисципліни «Безпека руху на залізничному транспорті» сприятиме формуванню професійної компетентності майбутнього фахівия з автоматики на залізниці.

Ключові слова: безпека руху, інтерактивні технологї, проблемне навчання, професійна компетентність.

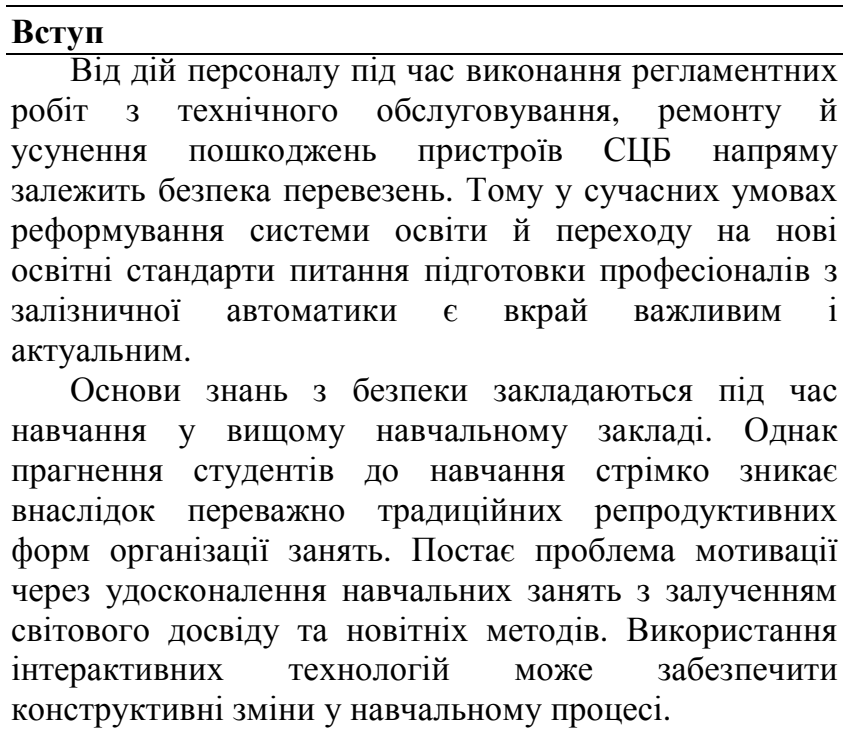

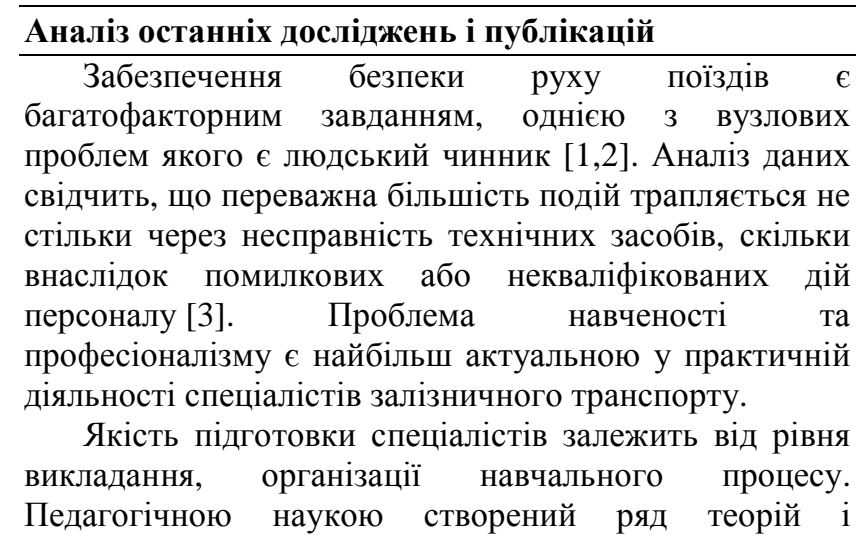

концепцій навчання [4]. Серед найбільш відомих такі теорії: проблемного навчання; програмованого навчання; розвиваючого навчання; контекстного навчання; особистісно-діяльного та особистісноорієнтованого навчання та ін. Однак на практиці ці розробки не набули широкого розповсюдження у зв’язку 3 відсутністю ефективних методів та форм практичної реалізації. Досі більшу частину занять в традиційному навчанні займає пасивне споглядання. Спрацьовує ефект Рингеймана - зі збільшенням чисельності групи знижується середній інтелектуальний внесок членів у вирішення проблеми.

Впровадження інтерактивних технологій та проблемного навчання у багатьох сферах підготовки спеціалістів у вищих навчальних закладах Східної Європи та Америки [5-10] дозволяє підвищити рівень зацікавленості, покращити ефективність навчання та рівень підготовки спеціалістів шляхом глибшого розуміння та стійкого утримання інформації. Але самостійної теорії інтерактивного навчання як такої не існує. Тому дослідження, присвячені інтерактивному навчанню, займають особливе місце.

\section{Мета}

Пошук найбільш ефективних засобів, форм i методів, направлених на активізацію навчальнопізнавальної діяльності, покращення рівня навченості майбутніх фахівців у галузі автоматики та телемеханіки залізничного транспорту шляхом впровадження сучасних технологій у викладання дисципліни «Безпека руху на залізничному транспорті». 


\section{Виклад основного матеріалу}

Втілення інформаційних технологій в усі сфери діяльності та зростаюча потреба у висококваліфікованих спеціалістах ставлять проблему перегляду системи підготовки спеціалістів на сучасних технологічних принципах. Доцільно врахувати досвід найбільш розвинутих держав, до яких відносяться США, Японія, Англія, Германія, Франція, де широко застосовуються інтерактивні методи [5,7,10,12].

Інтерактивні технології, що базуються на особистісно-діяльнісному підході, включають використання інтерактивних методів навчання (рис. 1).

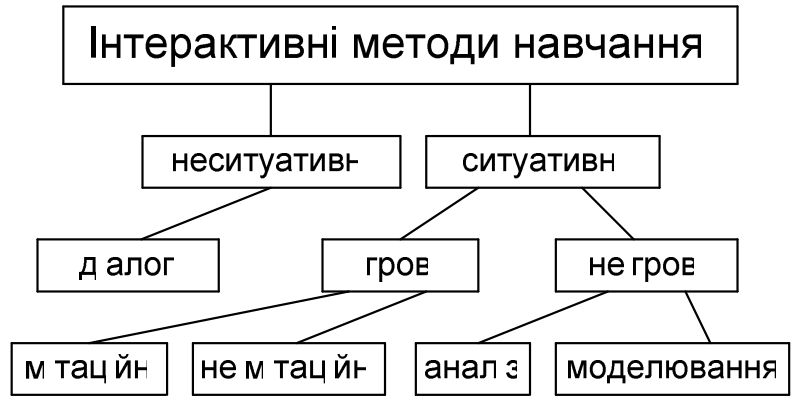

Рис. 1. Інтерактивні методи навчання

3 точки зору цільового призначення навчального процесу функціонально можна виділити:

1) формування й удосконалення професійних вмінь та навичок;

2) мотивація навчально-пізнавальної діяльності;

3) повідомлення навчальної інформації;

4) засвоєння досвіду та контроль результатів навчання.

Кожна функція найбільш ефективно може виконуватися в разі використання певних форм інтерактивного навчання.

1. Інтерактивне навчання грунтується, перш за все, на досвіді. Розпізнавання станів об'єктів та поточних ситуацій, прийняття відповідальних рішень, планування поведінки відносяться до основних інтелектуальних завдань повсякденної діяльності інженерів у дистанціях. Тому якість навчання повинна визначатися ступенем закріплення стійких навичок роботи при вирішенні типових завдань сфери майбутньої діяльності.

Компетентнісний підхід в системі вищої освіти підвищує увагу до рівня особистої освіти, наявності відповідних компетенцій, складовими яких є:

- $\quad$ знання, а не просто динамічна інформація, що швидко змінюється;

- уміння використовувати ці знання у необхідних ситуаціях;

- критичність мислення та адекватне оцінювання своєї діяльності й методів розв'язання ситуацій.
Застосування технології проблемнооріснтованого навчання $[11,12]$ базується на заданні ситуації, взятої з реальної професійної сфери, та підтримується візуальними матеріалами, статистичними даними, графіками.

Дії студентів при цьому формують «ланцюжок рішень» у такій послідовності:

a) ознайомлення 3 ситуацією, iï змістом та особливостями;

б) виділення основних чинників, що можуть реально впливати;

в) розуміння та пропонування рішення;

г) аналіз наслідків та вибір оптимального варіанта, прогнозування потенційних проблем та їх профілактики.

Проаналізувати задану ситуацію і побудувати послідовність виконання необхідних робіт із зазначенням дій усіх причетних до цього працівників; прийняти рішення щодо виключення пристроїв із залежностей та способу виключення; проілюструвати хід виконання робіт записами у Журналі огляду - всі ці завдання 3 «Безпеки руху на залізничному транспорті» можуть бути реалізовані на основі інтерактивних технологій як сукупності методів, прийомів, засобів інтерактивного навчання.

В наш час розвиток науки, техніки та технологій досяг такого рівня, коли стає реальним моделювання подій та складних задач за допомогою програмних та апаратних засобів. Інформаційне забезпечення дозволяє формувати програми у мультимедійному форматі з максимальним використанням усіх засобів наочності, включаючи рисунки, фотографії, відеоролики.

2. Процес навчання включає методи стимулювання навчально-пізнавальної діяльності, що можуть бути реалізовані різноманітними комп'ютерними програмами. В залежності від особливостей навчальної діяльності можна виділити такі типи інтерактивних програм:

- імітаційні та моделюючі;

- навчальні;

- контролюючі;

- розвиваючі ігри.

Одним зі шляхів мотивації до навчання є розробка інтерактивних демонстраційних та імітаційномоделюючих програм. Ці програми основані на графічних можливостях комп'ютера. Вони надають в розпорядження студента деяке середовище, набір можливостей та засобів їх реалізації, дозволяючи здійснювати комп'ютерний експеримент. Можна спостерігати на моніторі, наприклад, роботу апаратури залізничної автоматики. При цьому студент має можливість керувати процесом, змінюючи параметри подачею команд 3 клавіатури. Використання таких програмних засобів призводить до формування пізнавальних навичок, стимулює зацікавленість. 
3. Навчальні програми створені для організації інтерактивного діалогу, управління ходом навчання. Супроводжуються постановкою запитань для різного рівня підготовленості студентів: типових ситуаційних задач низького й середнього рівня та нетипових проблемних завдань вищого рівня. Так, якщо відповіді неправильні, програма може повернутися до повторного вивчення теоретичного матеріалу.

При цьому може використовуватися лінійна (рис. 2, а) або розгалужена (рис. 2,б) програма.

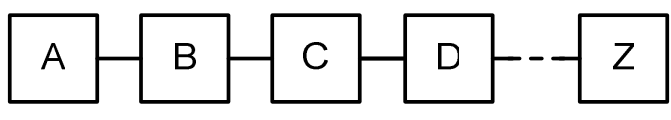

a

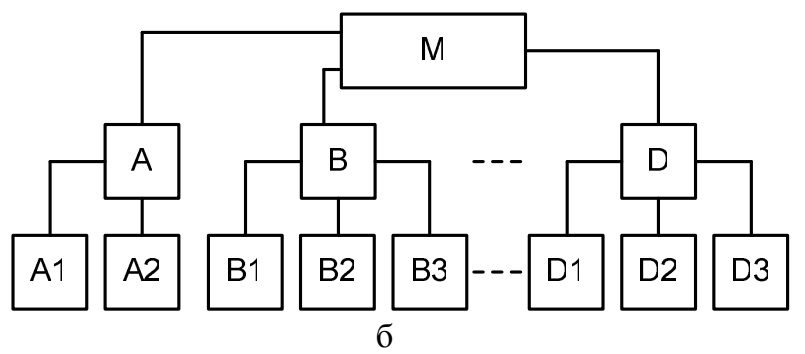

Рис. 2. Лінійна (а) та розгалужена (б) навчальна програма

Лінійна програма має такі особливості:

- дидактичний матеріал ділиться на невеликі кроки, що легко долаються;

- запитання не повинні бути занадто складними, аби студенти не втратили інтересу до навчання;

- в ході навчання відбувається інформування про правильність відповіді;

- всі студенти проходять по черзі всі кроки програми, але кожен робить це в зручному для нього темпі.

Основою лінійної програми є намагання уникнути помилок.

Розгалужена програма (рис. 2, б) направлена на знаходження недоліків у знаннях, виявлення незрозумілих тем дисципліни. Запитання мають на меті:

- перевірити, чи знає студент матеріал;

- у разі неправильної відповіді відправляти студента до джерел інформації;

- закріплення основної інформації за допомогою вправ;

- збільшення зусиль студента та ліквідацію механічного навчання через багатократне повторення інформації.

Можуть бути використані декілька видів організації програм навчального типу (рис. 3).

- послідовно-підготовчий алгоритм. Початковий елемент завдання відносно простий, готує до виконання наступного, більш складного. Заключні елементи мають достатньо високий рівень складності;

- паралельно-підготовчий алгоритм. Початкові елементи завдань незалежно один від одного готують до виконання наступного комплексного елемента високого рівня;

- послідовно-корегуючий алгоритм. Початкові елементи завдання мають високий рівень складності, а кожен наступний елемент коригує виконання попереднього, вказуючи на протиріччя у відповідях;
- паралельно-корегуючий алгоритм. Студенту пропонується комплексний елемент високого рівня, наступні елементи відіграють роль таких, що підказують, незалежно один від одного 3 різних позицій.

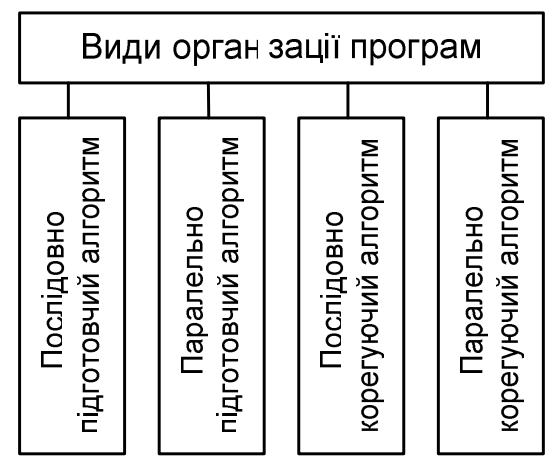

Рис. 3. Види організації програм

4. Для організації контролю знань в навчальних системах може використовуватися оцінка дій студента. Програма, що використовує «дерево рішень», організуе у навчальному інформаційному просторі рольову гру, імітує створення проблемних ситуацій. За допомогою цього методу можна на високому рівні перевіряти практичну складову навчання, визначити рівень знань без контрольних запитань. Застосування макетів залізничних пристроїв та систем автоматики, доповнених імітуванням пошкоджень 3 можливістю реального їх виявлення, адаптують навчальний процес до вимог практичного рівня засвоєння матеріалу. Навчальний процес стає інтегрованою у життя системою. При цьому з категорії концептуальних (на рівні понять) знання переходять у категорію алгоритмічних, процедурних знань - те, що прийнято називати «вміння», «технологія». 


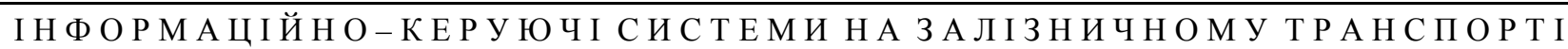

Втілення сучасних методів змінюе роль викладача 3 перекладача інформації на організатора i координатора навчальної діяльності для ефективного формування професійної компетентності майбутніх фахівців через наближення до змісту практичної діяльності. Головним завданням викладача при цьому $є$ такі:

- створення позитивних емоцій;

- підштовхування до використання інтуїції разом 3 розумінням;

- спостереження за коректністю вирішення ситуації.

Умовою застосування такого методу навчання $є$ залучення електронних джерел інформації, інтерактивних телекомунікаційних технологій.

Досвід свідчить, що використання інтерактивних технологій у навчальному процесі дозволяє суттєво покращити рівень знань $[4,10]$. У студентів зберігається на $20 \%$ більше знань фактичного матеріалу, й на $30 \%$ більше розуміння предмету. На рис. 4 показано сучасний стан успішності студентів різних груп 3 дисципліни «Безпека руху на залізничному транспорті» та очікуваний рівень покращення успішності в результаті втілення проблемно-орієнтованого навчання 3 використанням інтерактивних технологій.

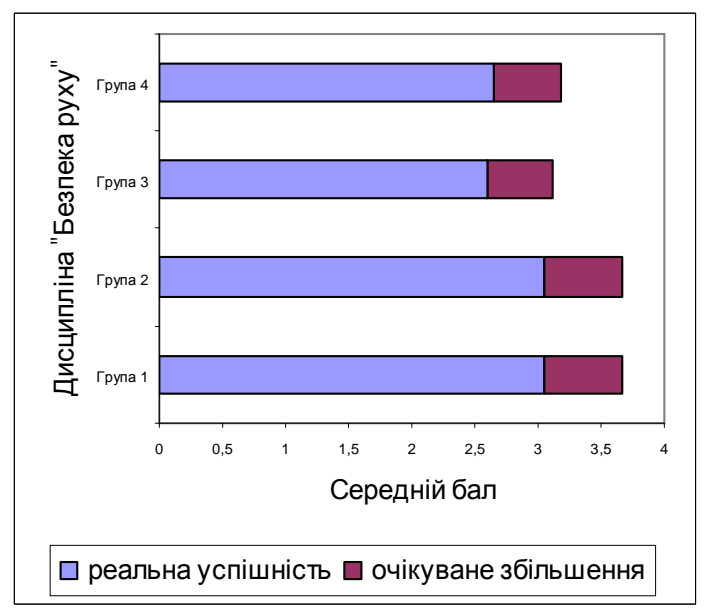

Рис. 4. Успішність студентів

Всі розглянуті аспекти повинні бути покладені в основу побудови сучасної освіти інженерів-електриків 3 автоматики та телемеханіки, які працюватимуть в реальному часі й реальному світі.

\section{Висновки}

Вивчення найбільш поширених сучасних освітніх технологій обгрунтовує доцільність застосування інтерактивних технологій для посилення ефективності навчання. Основна стратегія повинна бути спрямована на організацію середовища для самонавчання, експериментальних та практичних занять, де студенти мають можливість опановувати цілісну професійну діяльність.

Подано результати дослідження методів, форм i засобів реалізації інтерактивного методу навчання у навчальному процесі. Визначено сучасні вимоги та складові компетентності спеціалістів 3 автоматики. Розкривається сутність, класифікація форм та методів інтерактивного навчання, пропонуються технології і форми втілення методу при проведенні занять 3 «Безпеки руху на залізничному транспорті». Розглянуто умови реалізації та завдання викладача.

\section{Список використаних джерел}

1. Аналіз стану безпеки руху на залізницях України у 2014 році [Текст] / Укрзалізниця. Головне управління безпеки руху та екології. - К., 2015. C.3-90.

2. Railway safety performance in the European Union 2014. - European Railway Agency. - 2014. - 84 c.

3. Макаренко, Л. М. Вплив людського чинника на безпеку руху залізничного транспорту: аналітичний огляд [Текст] / Л.М.Макаренко // Залізничний транспорт України. - 2010. - №1. C. $46-51$.

4. Добрынина, Т.Н. Интерактивное обучение в системе высшего образования [Текст]: монография / Т. Н. Добрынина. - Новосибирск: Изд. НГПУ, 2008. - 183 c.

5. Tshibalo, A. E. The potential impact of computeraided assessment technology in higher education [Text] / A. E. Tshibalo // South African Journal of Higher Education, №21(6). - 2007. - P. 684-693.

6. Yakovleva N.O. Interactive teaching methods in contemporary higher education [Text] / N.O. Yakovleva, E.V. Yakovlev // Pacific Science Review №16. - 2014. - P.75-80 http://dx.doi.org/10.1016/j.pscr. 2014.08.016

7. Silverthorn, D. U. Teaching and learning in the interactive classroom [Text] / D. U. Silverthorn // Advances in Physiology Education. - Vol. 30. - 2006. - P. 135-140; doi:10.1152/advan.00087.2006.

8. Demikhova, N. Using PBL and Interactive Methods in Teaching Subjects in Medical Education [Text] / N. Demikhova, O. Prykhodko, A. Loboda, V. Bumeister, V. Smiianov, Y. Smiianov, V. Lukianykhin, O. Demikhov // Journal of problem based learning in higher education. - Vol. 4, No. 1, 2016 - P. 81-90 http://dx.doi.org/ 10.5278/ojs.jpblhe. v0i0.1227

9. Orekhov V.I., The role of interactive teaching methods in modern education [Текст] / V.I. Orekhov, T.R. Orekhova // Международный научный журнал «Символ науки» №6. - 2015. - С. 242-244

10. Keen-Rhinehart, E. Interactive Methods for Teaching Action Potentials, an Example of Teaching Innovation 
from Neuroscience Postdoctoral Fellows in the Fellowships in Research and Science Teaching (FIRST) Program [Text] / E. Keen-Rhinehart, A. Eisen, D. Eaton, K. McCormack // The Journal of Undergraduate Neuroscience Education (JUNE), Spring 2009, 7(2):A74-A79.

11. Grisham J.W. Problem-Based Learning (PBL) and Public Health: An Initial Exploration of Perceptions of PBL in Vietnam. EP Wright. [Text] / J.W. Grisham, A.L. Martiniuk, N. Joel // Asia-Pacific Journal of Public Health. - March 2015. - vol. 27, 2. - NP2019NP2027. - first published on February 14, 2012, p. 2019-2027.

12. Johnson M. A comparison of problem-based and didactic learning pedagogies on an electronics engineering course [Text] / M. Johnson, M.J. Hayes // International Journal of Electrical Engineering Education. - January 2016. - vol. 53, 1. - pp. 3-22. first published on July 23, 2015. - p. 1-20.

\begin{abstract}
А. В. Лазарев, М.в. Ушаков, Н. Н. Лазарева. Интерактивные технологии в преподавании безопасности движения. Соблюдение безопасности движения поездов зависит от действий работников по техническому обслуживанию и ремонту устройств автоматики. Применение интерактивных технологий в подготовке студентов по дисциплине «Безопасность движения на железнодорожном транспорте» способствует формированию профессиональной компетентности будущего специалиста по автоматике на железной дороге.
\end{abstract}

Ключевые слова: безопасность движения, интерактивные технологии, проблемное обучение, профессиональная компетентность.

O.V.Lazariev, M.V.Ushakov, N.M.Lazarieva. Interactive technologies in the teaching of railway traffic safety. Observance of the railway safety depends on the actions of specialists in the maintenance and repair of automation devices. The experience of implementation of interactive technologies and problem-based training in the most developed countries of the world is considered. The modern requirements and components of competence of specialists in automation are determined. Stimulation of educational and cognitive activity is realized by computer programs: educational, simulation and modeling, with the help of developing games. The use of mock-ups of railroad devices with imitation of damage adapts the learning process to the practical mastering of the material. The conditions of realization and tasks of the teacher in the problem-oriented study are considered. Implementation of the interactive technologies in the training of students on discipline «Traffic safety on the railways» will promote the professional competence of the future specialists in railway automation.

Keywords: railway safety, interactive technologies, problem training, professional competence.

Надійила 08.08.2017 p.

Лазарєв О. В., ст. викладач, Украӥнський державний університет залізничного транспорту, кафедра автоматики та комп'ютерного телекерування рухом поїзів, Харків, Україна. E-mail: lazal@ukr.net, ORCID ID: 0000-0002-0186-5896.

Ушаков М. В., ст. викладач, Украӥнський державний університет залізничного транспорту, кафедра автоматики та комп'ютерного телекерування рухом поїзів, Харків, Украӥна. E-mail: micush@kart.edu.иа, ORCID ID: 0000-0001-6270-4212.

Лазарєва Н. М., інженер, Украӥнський державний університет залізничного транспорту, кафедра автоматики та комп'ютерного телекерування рухом поїзів, Харків, Україна. E-mail: laznata@ukr.net, ORCID ID: 0000-0002-2387-6334.

Lazariev Oleksii, lecturer, Department of Automatic and Computer Telemechanic of Railway Traffic Ukrainian State University of Railway Transport, Kharkiv, Ukraine. E-mail: lazal@ukr.net, ORCID ID: 0000-0002-0186-5896. Ushakov Mykhailo, lecturer, Department of Automatic and Computer Telemechanic of Railway Traffic Ukrainian State University of Railway Transport, Kharkiv, Ukraine. E-mail: micush@kart.edu.ua, ORCID ID: 0000-00016270-4212.

Lazarieva Natalia, engineer, Department of Automatic and Computer Telemechanic of Railway Traffic Ukrainian State University of Railway Transport, Kharkiv, Ukraine. E-mail: laznata@ukr.net, ORCID ID: 0000-0002-23876334. 